\title{
Subordination of Women in Short Story of Kompas Newspaper
}

\author{
Sidiq Aji Pamungkas' ${ }^{1}$, Sarwiji Suwandi², Muhammad Rohmadi² \\ ${ }^{I}$ Master Student in Sebelas Maret University, Surakarta, Indonesia \\ ${ }^{2}$ Sebelas Maret University, Surakarta, Indonesia \\ sidiqajipamungkas@gmail.com
}

\begin{abstract}
The equality of gender roles between men and women is a problem / polemic due to differences in gender roles. Social agreements place women to be regulated by men in life. This study discusses subordination of women in short story of Kompas newspaper on 2017. This is important to understand because understanding about subordination of women can be used as a standard of behavior to achieve harmonious and democratic community life. This type of research is descriptive qualitative with content analysis strategies. The research data was obtained from short story documents published in the Kompas newspaper in July 2017 to December 2017. The sampling technique used was purposive sampling. Data collection techniques use library research techniques. Data validity uses theory triangulation. The results showed that the subordination of women in Kompas short stories in 2017 in the form of a decision to determine the number of children was a man's decision and the decision of a girl's mate was under a man's decision as the head of the family (patriarchal culture).
\end{abstract}

Keywords : subordinatio; gender; women; women's problems; short stories

\section{Introduction}

The equality of gender roles between men and women is a problem / polemic due to differences in gender roles. Men play gender roles in the public sphere and women play gender roles in the domestic sphere. This has an impact on the birth of women's struggles to equalize and equal rights. Meanwhile, the influence of gender roles has been firmly planted in various institutions, actions, beliefs, and desires so that it becomes a reasonableness (Bertens, 2001: 98; Sugihastusi \& Saptiawan I.H., 2007: 3). As a result, insofar as the community holds the belief that women lack physical and intellectual abilities than men, society tends to distinguish women in academia, forums and markets (Tong, 2009: 2). Therefore, knowledge of gender injustice needs to be understood to change the stigma that exists in society.

Cases of inadequate gender roles in Indonesia are very diverse. The Central Statistics Agency (BPS) survey in collaboration with the Ministry of Women's Empowerment and Child Protection (KPPA) in 2017 stated that 1 in 10 women aged 15-64 years experienced violence in the last 12 months (Auliani: 2017). In addition, BPS also stated the results of salary acquisition surveys between women and men had differences in the nominal wages obtained. The average wage of female workers in February 2017 is Rp 2.27 million per month and men earn an average salary of Rp 2.95 million per month (Fik: 2017). This means that women in Indonesia are in a lower position than men based on the results of the survey.

The background of taking research objects in the form of newspaper short stories is influenced by previous research. Some studies of feminism formulate the problem of forms of gender injustice that occur in the object under study. Pre-research literature studies found that research on feminism has been carried out in novels, folktales, books of short stories, puppet stories, figures of feminist women writers, literary figures, NU ulama books, customs, and paintings. The research titled feminism includes (1) "Permasalahan Wanita dalam Novel N.H. Dini: Analisis Sastra Feminis" by Nadjamudin in 2002, (2) "Karya Religius Danarto: 
Kajian Teori sastra Feminis" by Adji in 2003, (3) "Kiprah Perempuan Pengarang di Indonesia Pasca-Saman" by Wahyudi in 2005, (4) "Pemberontakan Perempuan Bali terhadap Diskriminasi Kelas dan Gender: Kajian Feminis Novel Tarian Bumi karya Oka Rusmini" by Windiyarti in 2008, (5) " Perempuan dan Negara: Kajian Feminisme dalam Konteks Sosial 'BH' Karya Agus Noor" by Woodrich in 2013 , (6) "Multiplisitas Wajah Rahim: Karya Seni sebagai Narasi Feminis (Refleksi Atas Pameran Tunggal Dewi Candraningrum 'Dokumen Rahim')" by Noviani in 2015. (7) "Feminisme dalam Pagelaran Wayang Kulit Purwo Tokoh Dewi Shinta, Dewi Kunti, Dewi Srikandi" by Ariani in 2016, and (8) "Feminisme dalam Pagelaran Wayang Kulit Purwo Tokoh Dewi Shinta, Dewi Kunti, Dewi Srikandi" by Eriyanti in 2016. Pe a research entitled feminism in a short story has been carried out, but the study analyzed short stories from one author or a collection of short stories. The study of feminism in newspaper short stories has not been done.

Gender roles are actually formed based on social agreement on the basis of the culture of civilization. As an example of social agreement and has become a fairness in society is patriarchal culture. Patriarchal culture gives men the dominance of power and does not provide equal roles for women. Patriarkat places women to play in the domestic sphere, namely serving husbands, educating children, and becoming good housewives. The dominance of power is held in full by a group of men who are free to determine their lives in the public sphere, but women are given a low socio-economic position. This means that there is discrimination from men to women.

Indonesia is one country that has a gender role problem. In Indonesia, especially Java, there are expressions such as women who are arranged (symbolizing the role of women who must be prepared), mattresses, wells, kitchens (symbolizing women carrying out duties to serve husbands), Swarga nunut hell katut (symbolizing happiness and sadness of women to husband), and so on. That is, these expressions help regulate women in subordinate positions under men.

Subordination is a form of gender injustice. Subordination places women to be regulated by men. Subordination of women can be interpreted as the process of placing women in unimportant positions. In other words, women hold positions below men in all areas of life.

Literary works tell the polemic of social life that is not much different from reality in the real world. Literary work is a form of expression related to phenomena that exist in social life. Literary works are generally imaginative, but the events told are logical (reasonable) and contain truth. Although short stories are a type of fictional work, events in short stories are dealt with in such a way as to fit the reality of life (Kennedy, 1983: 25). Literary works, including short stories, are one form of representation of culture or values that are owned by society. These values are derived from the socio-cultural reality of society that surrounds the life of the author. Socio-cultural problems are caused by imbalances in community life. Barker (2006: 60) states that there is a concept that contrasts ideology in terms of experience with the side of meaning related to social class power.

Short stories are appreciated in newspapers. The newspaper column in the Sunday edition is always given space for short story texts. Newspaper short stories in Indonesia are opened to the general public and given an appreciation in the form of money each loading so that everyone competes to send short stories in the hope of being published. Thus, short 
stories published in newspapers are the best short stories that have been selected from the many authors who sent them.

Based on the description above, subordination in short stories in newspapers is interesting to study. This study aims to describe and explain subordination of women in the short story of the Kompas newspaper. This is important to understand in order to realize gender equality between men and women.

\section{Review of Literature}

Discrimination against women in acting is a form of gender injustice. The feminism paradigm views women as having equal opportunities with men to do work in the public sphere, not only in the domestic sphere. However, the patriarchal system places women in a subordinate position under men so that women's freedom in determining their own destiny is hindered by the social, political and cultural legal systems. Therefore, research encourages feminism because of the question of why women play a subordinate role under men (Ryan, 2011: 179).

The patriarchal system is characterized by the existence of power, domination, hierarchy, and competition from men to women. The social legal structure and patriarchal politics must be removed in order to realize women's rights. In the patriarchal system, the social and political rules that give privileges to men are the cause of oppression of women. Feminism is a women's struggle to achieve equality in women's rights with men. In other words, feminism is a struggle for social transformation that aims to create a world of equality of rights for women and men through social equality (Djajanegara, 2000: 4; Humm, 2017: 160; Tong, 2009: 3).

The issue of femininism is the issue of gender roles. Gender in question is not a gender that means sex, but gender in the form of a role formed from social agreement on the basis of the culture of civilization. The word male and female refers to sex, while the word masculine and feminine refer to gender. The misconception occurs when sex and gender coalesce because the two concepts combine and match ways of acting with the biological nature possessed. Gender is different from gender (sex). Gender is not owned since birth. Gender is formed from something that is done or played in everyday life. That is, gender is inherent and influences the appearance and attitude that results in an authoritarian attitude towards the appearance and attitude of the person-persona itself. Unlike gender (sex), gender is not biologically classified based on reproductive traits such as sex. Gender is more pragmatic and feminist is more theoretical (Ratna, 2010: 227). Gender roles are formed by a set of behaviors that include appearance, attitude, personality, sexuality, work, etc. (Mosse, 2007: 3). Therefore, gender is social and sex is biological.

The demands of the feminist movement are the struggle for equality / rights between men and women and the demands of women to be given freedom from a low socio-economic position. Low values are given by the patriarchal system to feminine qualities such as "softness of behavior, humility, great empathy support, compassionate, intuitive / sensitive, emotional behavior, selflessness", while high values are given to masculine qualities such as "firmness behaves, aggressive in behavior, hardiness, rationality or the ability to think logically, abstractly and analytically without highlighting feelings "(Tong, 2009: 3). 
Feminism is a cultural construction to equalize rights in the distribution of gender roles that have been passed down for generations or culturally have entered into a generation of countless women (Bertens, 2001: 98). Many women are often marginalized, subordinated, and demeaned in the fields of politics, economics, and social life. The influence of the gender role has been firmly planted in various institutions, actions, beliefs, and desires so that it becomes a reasonableness (Sugihastusi \& Saptiawan I.H., 2007: 3).

Subordination of women can be interpreted as the process of placing women in unimportant positions. In other words, women hold positions below men in all areas of life. Differences in gender roles can lead to subordination of women to men. The views on women that women are irrational or emotional make women considered unable to appear in the lead so that women are in an unimportant position under men. The emergence of attitudes that place women in unimportant positions is a form of gender injustice. Thus, the starting point of gender injustice is rooted in gender understanding factors which actually strengthen the occurrence of subordination (Fakih, 2008: 15).

Women's subordination is caused by many aspects. In addition to the stereotypical aspects of women, cultural aspects also place women in a lower position than men. Djajanegara (2000: 31) explains that women in patriarchal culture are placed in the camps / realm of domestic work at home so that the impact on women is subordinated.

\section{Research Method}

This research is descriptive qualitative research with content analysis strategy. Qualitative research is a study to understand phenomena about what is experienced by the subject of research, for example understanding behavior, perceptions, motivations, actions, etc. that are done holistically by means of descriptions in the form of words in natural contexts and natural methods (Moleong 2014: 6). Data analyzed in the form of short story documents published in Kompas newspaper so that they are not bound by the place. The short story text used is the short story text published in the Kompas newspaper in the period July 2017 to December 2017.

The sampling technique in this study uses purposive sampling, which is looking for data that is in accordance with the needs of researchers. Researcher's needs are realist short stories. The researcher found four short stories from short stories published in Kompas newspaper from July 2017 to December 2019. The short stories studied were realist type short stories, not surrealist short stories that depicted stories such as dream life. Realist type short stories are short stories that tell events according to reality that is seen by the eye in social life. The short stories included Rumah-rumah Nayla by Djenar Maesa Ayu (DMA), Nio by Putu Wijaya (PW), Penagih Hutang Bersepeda Kumbang by Farizal Sikumbang (FS), and Pena by Rika. Of the four short stories, the researchers found two short stories which found subordination of women. The two short stories are Rumah-rumah Nayla by Djenar Maesa Ayu (DMA) and Penagih Hutang Bersepeda Kumbang by Farizal Sikumbang (FS). Data collection techniques use library research techniques. Satoto (2012: 115) states that data collection techniques commonly used are (1) observation, (2) communication, (3) interviews, (4) questionnaires, (5) questionnaires, and (6) literature studies. The triangulation used in this study is theory triangulation. 


\subsection{Result}

\section{Result and Discussion}

The researcher found two short stories which found subordination of women. The two short stories are Rumah-rumah Nayla by Djenar Maesa Ayu (DMA) and Penagih Hutang Bersepeda Kumbang by Farizal Sikumbang (FS). Subordination of Women in the 2017 Kompas Short Story is as follows.

(a) Decisions in Determining the Number of Children are Male Decisions.

In the short story Rumah-rumah Nayla were found satire that men held power in all decisions, including the number of offspring. DMA raises stories with female characters who live very well. All decisions are made on women or women given the freedom to determine their lives. Nayla is described as having free children and Nayla only chooses to have two children. Even though she did not have a male child and male offspring was very desirable, Nayla was still given freedom by her husband. Nayla said her life was a dream life. That is, many women crave life like Nayla's life, which is given the freedom to determine the number of offspring in her life. As a work written by women and a work is the result of contemplation of anxiety, it can be a satire. Here is a fragment of the story that raises the satire.

In just a few months of marriage, Nayla became pregnant and gave birth to a baby girl. And in just a few months after giving birth, Nayla was again pregnant and giving birth to another baby girl. Although having two toddlers did not make Nayla troubled because again the caregivers for each baby were provided. He also decided to have only two children, whereas usually for peranakan families, the presence of a baby boy is very expected. But again Nayla was blessed with luck. Her husband didn't mind at all. Life is so light. Life which for most people is a form of ideal life. (DMA, 2017)

The story above tells us that Nayla was lucky because Nayla's husband did not object to Nayla's decision to only have two children. Meanwhile, it was also told about the descendants of men (male lamin type men) in general is very expected. Nayla, who has two female children, was given the freedom of her husband to determine how many descendants she wanted. However, at the end of the paragraph a sentence that says "Life which for most people is a form of ideal life" indicates that women occupy the second position in making choices because the word dream has the intention of being coveted / dreamed of. Therefore, as a woman's work and literary works are the result of contemplation of anxiety over world reality, the DMA tries to give innuendo to men that women who are given the trust to be free to make decisions tend to be few so that it is said to be a form of ideal life for everyone .

(b) Girls' Matchmaking Decisions are Under the Decision of Men as Family Heads (Patriarchal Culture)

Short Story Penagih Hutang Bersepeda Kumbang karya Farizal Sikumbang (FS) is a short story in which there is a reflection of subordination to women in terms of mate. Female mate is determined / decided by the male head of the family due to holding firm to the patriarchal culture. Penagih Hutang Bersepeda Kumbang by FS tells Ida Union after graduating from high school in love with Udin Leman (Collecting Cycling Beetle Debt). Udin Leman is a mobile glassworker who can be paid in cash or credited (owed). Uni Ida got to know Udin Leman because Udin Leman often went to the house to collect debts in 
installment payments. Uni Ida is often entrusted with money by Amak (mother) to pay for the pan installments so they often meet. Relations between Uni Ida and Udin Leman were not sanctioned by Abah (father of the Ida Union). Abah went to Udin Leman's house so that Udin Leman would leave the village. Abah considers Udin Leman to have no clear origin. Abah brought a machete that made Udin Leman tremble with fear. Long story short, Udin Leman was forced to leave the village and part with Uni Ida. Thus, Uni Ida does not have the freedom to determine its mate. Ida's soul mate is determined by the head of the family. The following is a fragment of a story that shows subordination in terms of mate for women in the short story of Penagih Hutang Bersepeda Kumbang.

Uni Ida is just silent by bending his face to the floor. Do not dare look at Abak's face. "I don't want to hear if you meet him. I feel he is not a good person. Never connect with people who don't know their origin. You understand?"

Uni Ida did not respond to Abak's words. Her mouth was silent. Her body is stiff. She is like a statue. But Ida's tears were spilled. Wetting her cheeks. And Abak did not think about tears. For Abak, his decision must not be violated. Mak, don't dare answer. Mak just shut up. Rigid. But at the end of the meeting that night, Abak could blame Mak.(FS, 2017)

The fragment of the story above shows that Uni Ida is not given the freedom to determine its soul mate. The father of Uni Ida is the power of attorney to determine the match between Uni Ida. Even though Uni Ida really loves Udin Leman, Uni Ida is forced to surrender her love. Uni Ida cannot be with Udin Leman because the decision of Ida's father cannot be violated. Meanwhile, the mother of Uni Ida did not dare to do anything and obeyed the decision of the father of Uni Ida. Thus, the full power is in the hands of Ida's father. In other words, women are subordinated in determining their own mate.

\subsection{Discussion}

This study found the full power of men in determining the number of children and their mate. The social construction arises as a result of patriarchal culture in society. Kardiansyah (2017) stated an implication of colonial nuances that occurred in gender relations reflected in the novel The Scarlet Letter. In this case, the analysis proves the existence of a colonial construction in the form of dominance carried out by male gender on women's gender. This of course starts from stereotypes about the characteristics of women who are always considered weak and their status is lower than that of men. The stereotype seemed justified by describing the figure of Hester who was unable to acknowledge the father of the baby he was born with, and Hester's helplessness for Chillingworth's unpleasant treatment directed at him. Therefore, the relation of this research and Kardiyansah's research is that stereotypes in women lead to the emergence of stereotypes. In this study, the cause of the emergence of female subordinates is not only because of stereotypes, but also due to patriarchal culture. This research shows that women's subordination occurs because patriarchal culture gives full power to men as the head of the household.

In Scotland, the placement of women tested is not lower than that of men. The government tries to budget women's gender to create equality. O'Hagan (2017) introduces the concept of gender budgeting and discusses transformative potential. The introduction of a framework that benefits women in dismantling gender budgeting as a policy response to 
women's unequal economic status reflects feminist transformative intentions. In analyzing discursive shifts that are moving towards the use of a medium-term economic framework, such as government expenditure plans and economic strategies reflect that Scotland is built on a feminist economic perspective and highlights the importance of ensuring that equality is key. Gender budgeting aims to raise awareness of the different impacts on women and men on publicly, subnationally and locally funded policies and programs such as universities or health councils. Thus, the existence of more budgeting for women in the fields of education and health creates gender equality. Men do not think they are humbled and also do not consider it higher.

Subordination of women is not a process of evolution of male power which continues to be above (the strongest power). Subordination to women is caused by male selfishness formed by the concentration of culture. Fernandes and Leite (2016) draw a feminist poststructuralist approach that studies what constitutes the construction of female workers produced in two focus groups of Portuguese entrepreneurs when they discuss female subordinates. The study connects women in conception and the adequacy felt by women's bodies in the work context. Fernandes' analysis shows that the dual gender conditions of women entrepreneurs allow the emergence of two interpretive repertoire opponents that allow them to negotiate meanings about women's subordinate bodies and indirectly about women's bodies influencing position.

Subordiation of women is influenced by the existence of negative labels that harm women. Negative labels such as irrational, emotional, and so on women form the view of men becoming more self-confessed that they are rational. This view influences men's actions towards women, including subordination to women. Socio-cultural factors in the form of residence affect the level of education, religion, marital status, and the main occupation also influences perceptions. This perception influences actions so that negative labels on women determine subordination to women. Miller et al. (2009) examined the development of feminism that occurred. Miller and colleagues focus their research on developments and gender differences in the accessibility of gender stereotyped domains. It turned out that each of his beliefs and behaviors had been started according to gender groups since childhood so that gender knowledge had been embedded from the beginning of a person's life. At all ages, except for a little deviation in kindergarten, stereotypes of looks like beautiful, long-haired, wearing dresses, jewelry, and make-up, are the most thoughtfully prepared when children describe women. Conversely, sports activities and fighting traits, playing roughly are more prevalent in the description of boys. In particular, if a girl is determined by appearance then a boy who looks like a girl gets social sanctions from peers. Thus, stereotypes have been formed since boys and girls were children.

Gupta et al (2008) in their study related to the implicit and explicit impact of gender stereotyping on male and female intentions in terms of pursuing traditional careers such as entrepreneurship. Testing the entrepreneurial intention to use a sample of 469 business students to one of the 6 experimental conditions indicates that the hypothesis when entrepreneurship is associated with the characteristics of masculine stereotypes and feminine characteristics. Men who have a higher entrepreneurial score than women when there is no stereotypical information about entrepreneurship are presented showing that the social stereotypes that underlie entrepreneurial relationships with masculine / feminine characteristics can influence people's intentions. 


\section{Conclusion}

Subordination of women can be interpreted as the process of placing women in unimportant positions. In other words, women hold positions below men in all areas of life. This study found two short stories which found subordination to women, including Rumahrumah Nayla by Djenar Maesa Ayu (DMA) and Penagih Hutang Bersepeda Kumbang by Farizal Sikumbang (FS). The subordination of women of short stories in Kompas 2017 in the form of a decision to determine the number of children is a man's decision and the decision of a girl's mate is under a man's decision as head of the family (patriarchal culture).

\section{References}

Adji, P.S.E. (2003). Karya Religius Danarto: Kajian Kritik Sastra Feminis. Jurnal Humaniora, XV(1), 23-38.

Ariani, I. (2016). Feminisme dalam Pagelaran Wayang Kulit Purwo Tokoh Dewi Shinta, Dewi Kunti, Dewi Srikandi. Jurnal Filsafat, 26(2), 272-290.

Auliani, P.A. (2017). Survei BPS: Satu dari Tiga Perempuan Indonesia Pernah Jadi Korban Kekerasan. Retrieved from https://nasional.kompas.com/read/2017/04/05/07100021/survei.bps.satu.dari.tiga.perem puan.indonesia.pernah.jadi.korban.kekerasan.

Ayu, D.M. (2017). Rumah-rumah Nayla. Koran Kompas.

Barker, C. (2006). Cultural studies: teori dan praktik (hlm. 60). Yogyakarta: Kreasi Wacana.

Bertens, H. (2001). Literary Teory. New York: Routledge.

Djajanegara, S. (2000). Kritik Sastra Feminis. Jakarta: Gramedia Pustaka Utama.

Eriyanti, L.D. (2016). Pemikiran Politik Perempuan Nahdlatul Ulama (NU) dalam Perspektif Feminisme: Penelusuran Pemikiran Mainstream da Non-Mainstream. Jurnal Ilmu Sosial dan Ilmu Politik, 20(1), 69-83.

Fakih, M. (2008). Analisis Gender dan Transformasi Sosial. Yogyakarta: Pustaka Pelajar.

Fernandes, E. and Leite, R. (2016). Embodied women in the work context: The case of Portuguese businesswomen and their female subordinates. Women's Studies International Forum, 56, 45-55.

Fik. (2017). BPS: Rata-Rata Upah Buruh Wanita lebih Rendah Dibanding Pria. Retrieved from https://www.msn.com/id-id/ ekonomi/ekonomi/bps-rata-rata-gaji-buruh-wanitalebih-rendah-dibanding-pria/ar-BBAL7FH.

Gupta dkk. (2008). The Effect of Gender Stereotype Activation on Entrepreneurial Intentions. Journal of Applied Psychology, 93(5), 1053-1061.

Humm, M. (2017). Ensiklopedia Feminisme. Yogyakarta: Fajar Pustaka Baru.

Kardiansyah, M.Y. (2017). Tubuh dan Relasi Gender: Wacana Pascakolonial Dalam Novel "The Scarlet Letter" Karya Nathaniel Hawthorne. Poetika, V(1), 58-67.

Kennedy, X. J. (1983). An Introduction to Fiction (hlm. 25). Boston: Little Brown and Company.

Miller dkk. (2009). Accessibility of gender stereotypes of domains: Developmental and gender differences in children. Sex Roles, 60(11-12), 870-881.

Moleong, L.J. (2014). Metode Penelitian Kualitatif (hlm. 6). Yogyakarta: Remaja Rosdakarya. 
Mosse, J. C. (2007). Gender \& Pembangunan. Yogyakarta: Pustaka Pelajar.

Nadjamudin, S. (2002). Permasalahan Wanita dalam Novel N.H. Dini: Analisis Sastra Feminis. Humaniora, XIV (3), 1-20.

Noviani, R. (2015). Multiplisitas Wajah Rahim: Karya Seni sebagai Narasi Feminis (Refleksi Atas Pameran Tunggal Dewi Candraningrum "Dokumen Rahim”). Jurnal Kajian Seni, 1 (2), 103-113.

O'Hagan, A. (2017). Gender Budgeting in Scotland: A Work in Progress. Administration Journal, 65 (3), 17-39.

Ratna, N. K. (2010). Sastra dan Cultural Studies: Representasi Fiksi dan Fakta. Yogyakarta: Pustaka Pelajar.

Ryan, M. (2011). Teori Sastra: Sebuah Pengantar Praktis (Terjemahan). Yogyakarta: Jalasutra.

Satoto, S. (2012). Metode Penelitian Sastra (hlm. 115). Surakarta: Yuma Pustaka.

Sikumbang, F. (2017). Penagih Hutang Bersepeda Kumbang. Koran Kompas.

Sugihastusi \& Saptiawan I.H. (2007). Gender \& Inferioritas Perempuan. Yogyakarta: Pustaka Pelajar.

Tong, R. (2009). Feminist Thought: A More Comprehensive Introduction. United States of America: Westview Press.

Wahyudi, I. (2005). "Kiprah Perempuan Pengarang di Indonesia Pasca-Saman" dalam Jurnal Srinthil: Media Perempuan Multikultural. Jakarta: Desantara.

Windiyarti, D. (2008). Pemberontakan Perempuan Bali terhadap Diskriminasi Kelas dan Gender: Kajian Feminis Novel Tarian Bumi karya Oka Rusmini. Humaniora, 20(3), 286-294.

Woodrich, C. (2013). Perempuan dan Negara: Kajian Feminsme dalam Konteks Sosial “BH” Karya Agus Noor. Kawistra, 3(2), 117-226. 